\title{
THE ROLE OF THE $B$-PREFIX IN GULF ARABIC DIALECTS AS A MARKER OF FUTURE, INTENT AND/OR IRREALIS
}

\author{
Maria Persson
}

\section{UNIVERSITY OF LUND}

This paper presents arguments for a re-analysis of the $b$-prefix in Gulf Arabic dialects. Similar to several other dialects, Gulf Arabic possesses a $b$ prefix that is inserted before the p-stem (prefix form) of the verb. However, the Gulf Arabic $b$-prefix differs substantially from the one encountered in other Arabic dialects. According to most previous studies, the Gulf Arabic $b$-prefix encodes future tense or intentive mood or a combination of these. Based on a thorough survey of the use of this particle in modern speech, I suggest that it is used in Gulf Arabic today as a generalized marker of the irrealis mood rather than being limited to function as a future/intentive marker. Futurity is one - but not the only or necessarily the most important one - of its connotations. Meanwhile, another marker, rāh, emerges as an obvious future marker in some parts of the dialectal area.

\section{Introduction $^{1}$}

The Levantine and Egyptian dialects of Arabic possess a $b$-prefix that is inserted before the p-stem (prefix form) of the verb to form the indicative mood and/or cursive ${ }^{2}$, progressive or habitual aspect. In the dialect of

1 This study constitutes a part of a larger project on the typology of verb syntax and tense/mode/aspect morphology in Gulf Arabic, 'Verb Syntax in Gulf Arabic Dialects', funded by the Bank of Sweden Tercentenary Foundation. Initial reports from this study have been presented at various occasions (Persson 2006a, 2006b, 2008a, 2008b, 2008c). I would like to thank my Omani colleagues at the GAP institute in al-Ain/Buraimi who patiently answered my many questions, and curriculum director Tim Peverill who proofread an earlier draft of this article and contributed with his expertise in both Nizwa dialect and English language, as well as my employers who have supported me in every way and worked my teaching schedule around my research needs. The project would also not have been possible without the help of a large number of former GAP students who are now working in various areas of the Gulf and who introduced me to their local friends, colleagues and neighbours. Through them I received access to people's homes and obtained unique interviews with local women.

${ }^{2}$ A generalized, cursive aspect expresses a universal truth or ongoing event 
$\operatorname{Sana}^{\mathrm{c}} \overline{\mathrm{a}}^{\mathrm{j}}$ a $b$-prefix is likewise reported to be used to express the progressive and possibly the habitual. For Yemeni dialects the use of a $b$ prefix to indicate the future has been noted. ${ }^{3}$ Also in dialects in the Sudan, Nigeria and Chad a prefix $b i$ - or $b$ - appears to be in use. ${ }^{4}$ In Gulf Arabic dialects, too, a $b$ - is sometimes added to the p-stem of the verb. However, similar though it may be in form, this Gulf Arabic $b$-prefix differs substantially in usage, and possibly also in origin, from those mentioned above.

According to most previous studies, the Gulf Arabic $b$-prefix is used to encode future tense or intentive mood or a combination of these. As this study will show, however, the Gulf Arabic $b$-prefix is extensively used in both main and subordinate clauses with predicates encoding states/actions that are neither future to the moment of speech nor encode any sense of intent or volition. It is, for example, widely used in conditional clauses, mainly in the apodosis (result clause), but also in the protasis (if-clause) without any apparent temporal implications. Likewise, some informants use it somewhat consistently for the habitual past. Hence, although the $b$-prefix does occur in clauses with future timereference and/or intentive modality, its quality as a future marker and/or marker of the intentive mood must be questioned and other factors deciding its use must be explored.

In this paper, I present a survey of the use of the $b$-prefix in modern Gulf Arabic dialects and a discussion of the various temporal, modal and or aspectual uses for which it is employed. I suggest some possible ways to account for the use of the Gulf Arabic $b$-prefix in non-future and nonintentive contexts. In particular, I explore the usefulness of Tedeschi's (1981) theory of branching futures for explaining the use of the $b$-prefix in conditionals. However, the search for a unified accounting for the use of the b-prefix in futures, conditionals and habitual contexts leads beyond Tedeschi's theories to the suggestion that the $b$-prefix is employed in Gulf Arabic to mark some contexts as irrealis. A few other possible markers for the future and/or intentive have been noted in the literature on Gulf Arabic, viz. the particles $r \bar{a} h / h a$ - and the verb(s) baga/yabi 'to

or action.

${ }^{3}$ Cohen, D 1984, 281; Cowan, W. 1966, 417; Eksell 2006, 77-81.

${ }^{4}$ Eksell 2006, 81f. Eksell refers to the studies by Kaye 1976, 129, n. 86; Owens 1993, 108f and Reichmuth 1983, 286ff, but remarks that the usage and function of the $b$-prefix in these dialects remain rather unclear. Eksell also points to the use of $b$-prefixes for future/intention/volition in other Semitic languages viz. various historical and modern forms of Aramaic (92-94). 
want'. These were included in this study for comparison with the $b$ prefix.

The study is based on a corpus of twenty-three hours of recorded authentic speech. The interviews took place mostly in people's homes during 2006-7, and were recorded by myself and by local staff. $^{5}$ Transcriptions of database material have been made with the purposes of this study in view. This article deals with syntactical and morphological traits in language, but not with phonology. The database covers dialect areas that differ from each other phonologically, for example, in the way certain letters are pronounced. Such differences have not been consistently noted in the transcriptions. Rather, to some extent, an attempt has been made towards a more unified representation of words to make it easier for readers who are not so well acquainted with the phonological peculiarities of each of the Gulf dialects to recognize words and read the examples given.

Tense, mood and aspect in Gulf Arabic 6

A general comparison between classical Arabic and modern Arabic dialects reveals that tense plays a more prominent role in the dialects and that some dialects have developed fairly comprehensive systems of tense/mood/aspect markers. ${ }^{7}$ According to Eksell, there is a general tendency to renew the ancient cursive aspect. This, she says, is accomplished by developing particular markers distinguishing the progressive/progressive-habitual, the imminent/volitive and the future. The old, unmarked imperfect form then contrasts with these to denote the cursive aspect in general. ${ }^{8} \mathrm{In}$, for example, the urban Levantine and Egyptian dialects, elaborate temporal systems have been created. Thus,

${ }^{5}$ Gulf Arabic as defined in the project comprises the dialects of southern Iraq, Kuwait, Bahrain, Qatar, eastern Saudi Arabia, Oman and the UAE.

${ }^{6}$ For a definition of tense, mood and aspect as used here, see Comrie 1976, 3, 1985, 6, 9 and Palmer 2001, 1. Palmer gives a concise definition of TMA saying that 'Tense, rather obviously, is concerned with the time of the event, while aspect is concerned with the nature of the event, particularly in terms of its 'internal temporal constituency' (Comrie 1976, 3). Modality is concerned with the status of the proposition that describes the event'. Cf. also Bybee et al. 1994, 176-181; Givón 1995, 112; Ingham 1994, 117f; Trask 1993, 92, 174f; Van Valin and LaPolla 1997, 41.

7 Comrie 1976, 80 n.1; Cuvalay-Haak 1997, 217-224, 238f; Holes 2004, 217ff, 226ff; Kaye and Rosenhouse 1997, 291, 304f; Mitchell and El-Hassan 1994.

${ }^{8}$ Eksell 2006, 79. 
in Syrian dialect we have a basically temporal tripartite system with past; present; future where the past is signified by the s-stem (suffix form) of the verb or the active participle; the present by the p-stem of the verb; and the future by the particle $r \bar{a} h$ combined with the p-stem of the verb. For compound tenses various forms of $k \bar{a} n a$, 'to be', is used as an auxiliary. In addition, there are examples of modal particles such as the prefix ${ }^{c} a m(m a)$ - which is added to the p-stem of the verb to express the progressive. The already mentioned $b$-prefix in this dialect signals indicative mood and has also been suggested to have aspectual functions. ${ }^{9}$

The dialects of the Arabian Peninsula, however, are comparatively poor in terms of modal or temporal markers. ${ }^{10}$ Ingham says, describing the Najdi dialect of Saudi Arabia that:

When contrasted with the modal auxiliary verbs of English, [...] Turkish or [...] Swahili, which are morphologically and distributionally definable classes of elements, the Najdi modals appear as a rag-bag of elements derived from verbs, adjectives and primitive particles and rather vaguely differentiated from certain other elements on the periphery of the group. ${ }^{11}$

According to Ingham, Najdi Arabic, like Classical Arabic, is an aspectcentred system. Although he does recognize sporadic signs of a developing tense-based system within the main structure, he devalues any overt tense markers that may appear in the dialect by believing them to stem largely from direct or indirect influence from other Arabic dialects. ${ }^{12}$

The temporal and modal system of Gulf Arabic appears to be quite rudimentary. Comrie holds (classical) Arabic to be a language with 'combined Tense/Aspect oppositions' considering the distinction between 'imperfect' and 'perfect' in Arabic to signal both aspect and relative tense. ${ }^{13}$ Ingham, in his study on the Nadji dialect in Saudi Arabia, describes Arabic as 'a language of the type showing Aspect with tense implications'. ${ }^{14}$ Holes, writing about the conservative verb morphology of Bedouin dialects and referring to data from Abboud (1964), comments that no system of modal particles has developed in the

\footnotetext{
${ }^{9}$ Ebert 2000, 776f; Eisele 1990, 184-190; Holes 2004, 226ff, 366ff.

10 Brustad 2000, 241; Holes 2004, 218f, 226, 236f; Ingham 1994, 87,117ff.

11 Ingham 1994, 117.

12 Ibid., 87ff, 109.

13 Comrie 1976, 78.

14 Ingham 1994, 87.
} 
dialect of the Nadjdi town of Ha ${ }^{\circ i 1} .{ }^{15}$ However, concerning the urban Gulf Arabic dialects, he remarks that:

The Bedouin-descended dialects of the seaports of southern Iraq and the Gulf littoral are an interesting typological compromise between the reductional tendencies of the Levant cities and the conservatism of inner Arabia, which again reflect the sociolinguistic history of their speakers. ${ }^{16}$

Holes goes on to say that a partial system of mood particles has developed in the town dialects in Kuwait and Bahrain for the expression of future intention. His conclusion is, though, that mood marking in the Bedouin dialects and particularly those of the Arabian Peninsula is less fully evolved. ${ }^{17}$ Brustad, finally, concludes that the dialects she studies, including the Kuwaiti dialect, are basically aspectual, and especially so in narratives. Basic time-reference is established around the moment of speech but other devices such as adverbs and context are used to change the temporal reference point. A special group of verbs that she calls 'time verbs' with kāna as its central member have as their primary function to establish time-reference. ${ }^{18}$

Previous studies on the Gulf Arabic b-prefix and other suggested markers for future tense

The Gulf Arabic (GA) $b$-prefix has held a prominent position in what has previously been written concerning future tense in GA. In both older and more recent research on Gulf Arabic the $b$-prefix is presented as a marker of future tense. ${ }^{19}$ Johnstone considers it to have future meaning with a sense of volition in Kuwaiti, Bahraini and Qatari dialects. He also mentions its use to signal future tense in the dialects of the Trucial Coast. ${ }^{20}$ Qafisheh mentions the verb baga 'to want' with a volitive meaning, but does not seem to include the $b$-prefix in his description of

\footnotetext{
15 Holes 2004, $123 \mathrm{f}$.

${ }^{16}$ Holes 2004, 124.

17 Ibid., 123-125, 226.

18 Brustad 2000, 186, 202, 367.

19 'Older' here is, however, not to be taken as 'very old'. Thus the $b$-prefix does, for example, not at all appear in Reinhardt's survey of Omani (and Zanzibarian). Future tense is marked in his material with the prefix ha-. Cf. Reinhardt 1894, 149 f.

20 Johnstone 1967, 143, 152, 163, 169. The data under the heading 'the Trucial Coast' in his study comprise recordings from Abu Dhabi and Dubai as well as from the Buraimi oasis on the border between today's UAE and Oman.
} 
Gulf Arabic grammar. ${ }^{21}$ Brocket finds the $b$ - to be used for pure future tense - without any implication of will or intent - in his recordings from 1979 and 1980 of the dialect in the Omani coastal town al-Khabura. He further makes the rather categorical statement that the use of this $b$-prefix is 'restricted to future meaning' and that future tense is almost always marked by this prefix in his data. ${ }^{22}$ Brustad says that the Kuwaiti $b$ seems to indicate both future and intentionality, at least in the speech of one of her informants. She also reports one instance where she interprets the use of $b$ - as marking intention in opposition to another particle ( $r \bar{a} h)$ denoting future tense. ${ }^{23} \mathrm{~A}$ differentiation in the usage of $b$ - and $r \bar{a} h$, though a somewhat different one, was noted by Johnstone in his data from Kuwait and Bahrain. There, he found that $b(i)$ - usually has the sense of volition whereas răh usually indicates intention. ${ }^{24} \mathrm{Al}-\mathrm{Ma}^{\mathrm{c}} \mathrm{tu} q$, also describing a Kuwaiti dialect, recorded a use of the $b$ - for the near future. ${ }^{25}$ Holes relates that the verb yabi, 'want', (in the form yabba) is used together with the p-stem of the verb in the Shiite dialects of Bahrain (Bahārna) to express both 'proximate intention' and 'wanting.' In Gulf littoral dialects in general, however, he observes a distinction between $b a-/ b i$ - expressing intention (baru: $h$ 'I'm going to go') and $y a b b i+v e r b$ for volition (Pabbi aru: $h$ 'I'd like to go'), and he concludes that $b a-/ b i$ has lost the volitional sense of the verb(s) it derives from. ${ }^{26}$ According to Al-Tajir, $b(i)$-, which he also derives from yabi, is employed in Bahāarna to indicate a future action. ${ }^{27}$ Feghali, finally, simply states that the future in Gulf Arabic can be (but not necessarily is) expressed by the prefix $b(a)$ - added to a $\mathrm{p}$-stem of the verb. The use of the $b$-prefix expresses an assumption about a future event. ${ }^{28}$

The Najdi dialect of Western Saudi Arabia falls outside of the scope of this study but is, nevertheless, interesting for comparison. There, Ingham reports, both the full form of the verb baga/yabi, 'to want', and

\footnotetext{
21 Qafisheh 1977, 59, 224-229.

22 Brocket 1985, 21f. Khabura is a town on the coastal line between Sohar and Muscat in the Batina region.

23 Brustad 2000, 242f. The scarcity of her data, however, prevents any further conclusions. See also my comments on her examples in footnote 58 below.

24 Johnstone 1967, 143, 152.

25 Al-Ma ${ }^{\mathrm{c}}$ tūq 1986, 195.

26 Holes 2004, 247 n.29.

27 Al-Tajir 1982, 80, 110.

28 Feghali 2004, 62.
} 
its reduced form $b$ - are used to express plain future, future of intent and imminent future as well 'being on the point of' ${ }^{29}$ Ingham further reports that the basic meaning of the $b$-prefix in the Najdi dialect is 'wish/intend'. ${ }^{30}$

The status of the $b$-prefix in the Gulf Arabic dialects thus seems to be rather unclear and in need of a more consistent and thorough study. This treatise is an attempt towards that end.

\section{Database}

The present study is based on a database of twenty-three hours of recorded speech from Bahrain, Kuwait, Oman, Qatar and the UAE. ${ }^{31}$ The 80 informants are village or town people representing over 20 different cities and villages. ${ }^{32}$ Most of them are university educated although around $20 \%$ have little or no schooling. The majority of my informants (70\%) are women. The recordings are largely of narrative or expository character but also include a fair amount of dialogue.

From this database, comprising at the moment about 4,000 analysed predicates, I have initially selected all predicates that have future timereference i.e. that are liable to encode future tense as well as future in the past. Among the 882 instances thus collected are both main and subordinate clauses; final, conditional and temporal clauses as well as complement clauses. In addition to these, I have included in this study all instances in my database of the $b$-prefix and $r \bar{a} h^{33}$ together with the occasional räyih and $h a_{-}{ }^{34}$ that was found in the database as well as all instances of the verb yabgilyabi, 'to want.' Only two instances of rāyih, 16 instances of $h a^{35}$ and one of the combination răh ha-were found.

29 Ingham 1994, 120f. This use of baga/yabi may be compared to the use of widd/bidd in some dialects. See for example Jong 2000, 238f, 325f, 401, 484f, 530, 572f; Michell and Hassan 1994, 19f, 25f, 38ff.

30 Ibid., 201, n.69.

31 The database is still under construction. Hence, the 23 hours used for this study constitute a part of the total corpus.

32 A few informants from Oman and the UAE are of Bedouin origin but have been settled for a generation or more.

33 This particle was mentioned by Johnstone 1967, 143,152 as a marker of (future) intent in the dialects of Bahrain and Kuwait. Brustad 2000, 234, 241, too, notes the use of $r \bar{a} h$ as a future marker in the Kuwaiti dialect.

34 This particle was recorded by Reinhardt 1894, 149f as the future marker in Omani dialect.

35 All but one of the 16 instances of $h a$ - were from one informant, a young mother from Abu Dhabi. The other single instance was recorded in the speech 
These 19 instances have, for the purposes of this treatise, been counted together with $r \bar{a} h$. Lists of verbs in the same form such as, 'He will peel, chop and cook the onions,' were counted as one single instance in the corpus and the number of predicates with future time-reference was thus reduced to 851 .

According to these criteria, a total of 1,012 instances have been collected. The number of predicates with future time-reference is, as said, 851 whereof 385 are preceded by $b$ - or răh and 4 are preceded by the verb yabgi/yabi, 'to want' whereas 462 are unmarked. The other part of the database viz. predicates with time-references other than future that are preceded by $b$ - or răh amount to 138 instances. As for the verb yabgi/yabi, 'to want', 23 instances of non-future use of them were found.

Although the whole database is more evenly distributed, the part that was selected according to the above criteria turns out to be dominated by material from Oman and the UAE and is divided on the countries as follows:

Table 1. Distribution of the defined portion of corpus over countries

\begin{tabular}{lcc}
\hline Country & Futures & Others \\
\hline Bahrain & 88 & 7 \\
Kuwait & 107 & 3 \\
Oman & 305 & 47 \\
Qatar & 62 & 10 \\
UAE & 289 & 71 \\
\hline Total & 851 & 138 \\
\hline
\end{tabular}

The use of $\mathrm{b}$ - and rāh in clauses with future time-reference

$45 \%$ of the 851 instances of future time-reference in the data base are marked with $b$ - or $r \bar{a} h$. This could indicate, in accordance with Johnstone's observations, that they are possible, but not necessary, markers of future tense. A short survey of the grammatical contexts (types of clauses) with future time-reference in which these markers are used vs. not used reveals the pattern shown in the tables 2 and 3 (overleaf). We find that $b$-/răh are relatively sparingly used in complement clauses and purpose clauses. Purpose clauses are dependent contexts and would typically be encoded as subjunctive/jussive in languages that mark grammatical mood. On the other hand, complement clauses can be both and the most frequent use of $b$-/răh with future timereference is in ordinary main clauses. ${ }^{36}$ They are rather extensively used

of an elderly, Qatari male.

36 Cf. Givón 1995, 125f; Khan 1988, 40; Noonan 1985, 91f; Persson 1999, 
in result clauses of conditions but there is also a fair amount of apodoses without any particle/prefix. Grammatical structure of the sentence does, in other words, not seem to play an important role in the use of these markers, nor does any straightforward indicative/subjunctive mood distinction appear to be at hand.

\begin{tabular}{|c|c|c|c|c|}
\hline Type of clause & $b i-$ & $r \bar{a} h$ & 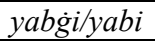 & Total \\
\hline main clauses & 190 & 65 & - & 255 \\
\hline object complement clause & 21 & 17 & 2 & 40 \\
\hline subject complement clause & 2 & 1 & - & 3 \\
\hline subordinate temporal clauses & 6 & - & - & 6 \\
\hline relative clause & 14 & 3 & - & 17 \\
\hline consequential clause & 2 & 1 & - & 3 \\
\hline purpose clause & 6 & - & & 6 \\
\hline protasis (if-clause) & 8 & - & 2 & 10 \\
\hline apodosis (result clause) & 30 & 19 & - & 49 \\
\hline Total & 279 & 106 & 4 & 389 \\
\hline
\end{tabular}

Table 3. Types of clauses with future time-reference without any of the surveyed particles/prefixes

\begin{tabular}{lc}
\hline Type of clause & Total \\
\hline main clause & 218 \\
object complement clause & 105 \\
subject complement clause & 36 \\
subordinate temporal clause & 11 \\
relative clause & 18 \\
consequential clause & 5 \\
purpose clause & 29 \\
protasis (if-clause) & $19^{37}$ \\
apodosis (result clause) & $20^{38}$ \\
imperative & 1 \\
\hline Total & 462 \\
\hline
\end{tabular}

The use of b- and rāh in non-future contexts

The 161 clauses with verbs preceded by any of the prefixes/particles that have other than future time-reference are distributed as can be seen in Table 4 (overleaf):

200f and 2002, 109-122, 134-7. See also Palmer 2001, 111-131. Generally speaking, complements of assertions are commonly marked for the indicative whereas complements to non-assertions are marked as dependent (subjunctive). Cf. Palmer 2001, 3f, 111.

37 Whereof 12 s-stems of the verb, 1 AP and 6 p-stems of the verb.

38 Whereof 2 s-stems of the verb, 1 AP and 17 p-stems of the verb. 
Table 4. Types of non-future clauses where $b-$, rāh or bagalyabi occur

\begin{tabular}{lllcc}
\hline Type of clause & $b-$ & $r a ̄ h$ & $b a \dot{g} a / y a b i$ & Total \\
\hline main clause & 43 & 1 & 12 & 56 \\
object complement clauses & 3 & - & 6 & 9 \\
relative clause & 1 & - & 3 & 4 \\
consequential clause & 2 & - & - & 2 \\
protasis (If-clause) & 21 & - & 2 & 23 \\
apodosis (result clause) & 56 & 11 & - & 67 \\
\hline Total & 126 & 12 & 23 & 161 \\
\hline
\end{tabular}

The non-future contexts with $b$ - or $r \bar{a} h$ comprise 27 sentences with present time-reference, 55 with past time-reference and 56 with no specific time-reference. The latter are mainly conditional clauses where relative tense is not stated. The 23 instances of bagalyabi are divided on 16 sentences with present time-reference, 5 with past time-reference and 2 with no specific time-reference.

The first conclusion to be made is that $r a \bar{h}$ is hardly ever used in nonfuture contexts with the exception of apodoses. This supports its status as a future marker. The second important observation to make is the very extensive use of $b$-, and to some extent $r \bar{a} h$, in conditional clauses. Of 138 occurrences of $b$ - or $r \bar{a} h$ in non-future contexts, 88 instances (64\%) are in conditional clauses. Second to this comes the use of $b$ - in ordinary main clauses with 43 occurrences $(31 \%)$. We will start a closer look at non-future usages of $r \bar{a} h$ and $b$ - by examining these conditional uses.

\section{Conditional clauses}

The extensive use of our presumed future markers in conditional clauses is noteworthy. Clive Holes writes about conditionals that:

an s-stem verb is used to express the condition even though the action to which it refers is in the future, relative to the time of utterance. [...] These observations apply to MSA, and also to the Bedouin-type dialects, although they are becoming less true of the urban dialects, in which the s-stem $/ \mathrm{p}$-stem distinction has evolved further towards a true tense system, and p-stem verbs (= 'non-past') are often used in 'open' conditionals. ${ }^{39}$

That the future marker is used in apodoses with future time-reference need not be surprising. To the contrary, Bybee, Perkins and Pagliuca found that future markers are common in apodoses where predictions are made. They conclude that 'apodoses are prime environments for future grams' ${ }^{40}$ However, in the present Gulf Arabic database the $b$ - prefix is

\footnotetext{
39 Holes 2004, 218.

40 Bybee et al. 1994, 274. The use of future markers in conditionals is a new development in written Arabic. Cf. Badawi, Carter and Gully 2004, 365, 654. In
} 
used not only in apodoses with future time-reference but also in apodoses with past or present time-reference:

1. an-nās $b$-yikūnu 'āyšs̄n fi hiām. At-tac ${ }^{c}$ limm ma $b i$-yikūn nafs al-ḥēn the-people $b$-be3pl.m.p-stem live.pl.m.AP in tents. The-teaching neg $b$-be3sg.m.p-stem same the-time

(If I had lived 20 years ago) people would be living in tents. Education would not be like it is now. ${ }^{41}$

2. Hiyya ma $b$-ikūn fîh hada t-tațawwur, at-taqaddum she neg $b$-be3sg.m.p-stem in.it this the-development, the-progress (if I had lived 20 years ago) This development, progress, wouldn't be there. ${ }^{42}$

3. ma kunt $r a \bar{h}$ atqabbal at-taġyīr bi suhūla neg be1sg.s-stem $r a \bar{h} h$ accept1sg.p-stem the-change with easiness (If I had lived in a small village on the countryside) I would not easily have accepted change. ${ }^{43}$

Furthermore, there are a significant number of instances where the $b$ prefix is used in protases:

4. al-walad ida $b$-izzawwağ matalan zoğteh tgūl... the-boy if $b$-marry3sg.m.p-stem for.example wife.his say3sg.f.p-stem If a boy is getting married his (espoused) wife will say... ${ }^{4}$

Only conditional clauses introduced by either of these particles were included in the study so far. In order to try and throw light upon what might trigger the use of $r \bar{a} h$ and $b i$ - in conditional clauses I will now expand the study to include all conditional clauses found in the original data base. These will then be examined in search for any consistency in, and possible motivation for, the use of $r \bar{a} h$ and $b$-.

The total number of protases (conditional main clauses) in the whole data base at its present stage is 121 . Of these, 29 have future timereference. The number of apodoses (result clauses to conditions) is 170 of which 68 have future time-reference. These distribute as follows over p-stem verbs preceded by $b$-prefixes or $r \bar{a} h$, s-stem verbs and other types of predicates:

Gulf Arabic it was, however, recorded already by Reinhardt 1894, 287-290.

41 Teenage schoolgirl, al-Ain, UAE.

42 Middle-aged well-educated female, al-Ain, UAE.

43 Young, well-educated male, Muscat, Oman.

${ }^{44}$ Elderly, upper-class male, Kuwait. 
Table 5. Distribution of verb forms and markers in protases (no instances of $r a \bar{h}$ or similar)

\begin{tabular}{lccccc}
\hline $\begin{array}{l}\text { Time } \\
\text { reference }\end{array}$ & $b-$ & $\begin{array}{c}\text { Zero } \\
\text { marking }\end{array}$ & $\begin{array}{c}\text { s- stem } \\
\text { verb }\end{array}$ & Other & Total \\
\hline Future & 8 & 6 & 14 & 1 AP & 29 \\
Past & 1 & 5 & 13 & - & 19 \\
Present & 8 & 6 & 1 & - & 15 \\
No explicit & 12 & 14 & 30 & 1 masdar, 1 imperative & 58 \\
\hline Total: & 29 & 31 & 58 & $\begin{array}{c}\text { 1 masdar, 1AP, } \\
\text { 1 imperative }\end{array}$ & 121 \\
\hline
\end{tabular}

Table 6. Distribution of verb forms and markers in apodoses

\begin{tabular}{lcccccc}
\hline Time reference & $r \bar{a} h$ & $b-$ & $\begin{array}{c}\text { Zero } \\
\text { marking }\end{array}$ & $\begin{array}{c}\text { s-stem } \\
\text { verb }\end{array}$ & Other & Total \\
\hline Future & 19 & 30 & 16 & 2 & $1 \mathrm{AP}$ & 68 \\
Past & 5 & 23 & 8 & 4 & $1 \mathrm{AP}$ & 41 \\
Present & - & 4 & 5 & - & - & 9 \\
No explicit & 4 & 29 & 17 & 1 & $1 \mathrm{PP}$ & 52 \\
\hline Total: & 28 & 86 & 46 & 7 & $2 \mathrm{AP}, 1 \mathrm{PP}$ & 170 \\
\hline
\end{tabular}

The use of the $b$-prefix in apodoses is particularly striking: $50 \%$ of all the result clauses in the corpus contain verbs prefixed with this particle. Of these one-third $(35 \%)$ have future time-reference. The share of apodoses that are futures introduced by $b$-comprises less than a fifth $(18 \%)$ of the total number of apodoses. It is also noteworthy that almost a quarter of the protases have p-stem predicates with $b$-prefix and that $b$-prefixes do not dominate among protases with future time-references. The data is too small to make any far reaching conclusions. It is, however, clear that the $b$-prefix is used in conditional clauses to a much greater extent than as an indicator of future time-reference. Indeed, time-reference, at first glance, does not seem to play a role here at all, especially if we consider the significant use of the $b$-prefix in apodoses with past timereference. In languages in general, conditional clauses are neutral in terms of time-reference. ${ }^{45}$ Still, such a frequent use of an assumed future marker in conditionals calls for some explanation. I will discuss possible motivations for the use of the $b$-prefix in conditional contexts below. Before that we will, however, take a look at other contexts than the conditional clause where $b$ - and/or $r \bar{a} h$ are used with timereferences other than future.

45 Cf. Cuvalay 1994, 235, Kaye and Rosenhouse 1997, 308. 
Other uses of b- and/or rāh with non-future time-reference

Table 4 showed the sentence types in which $b$ - and $r \bar{a} h$ are used with time-references other than future. The distribution, without the conditionals, is shown again for reference in Table 7.

Table 7. Types of non-future, non-conditional clauses where $b-, r \bar{a} h$ and baga/yabi occur

\begin{tabular}{lcccc}
\hline Type of clause & $b-$ & $r a \bar{h}$ & baga/yabi & Total \\
\hline main clause & 43 & 1 & 12 & 56 \\
object complement clauses & 3 & - & 6 & 9 \\
relative clause & 1 & - & 3 & 4 \\
consequential clause & 2 & - & - & 2 \\
\hline Total & 49 & 1 & 21 & 71 \\
\hline
\end{tabular}

There is only one instance of $r \bar{a} h$ with other time-reference than future, but 49 examples of the use of $b$ - in non-future context outside of the conditional use of these particles. In other words, the corpus contains a considerable number of ordinary main clauses with time-references other than future where the $b$-prefix is used. Hence, although the $b$-prefix is extensively used in clauses with future time-reference, its quality as a future marker seems less obvious.

We saw in Table 4 that $r \bar{a} h$ only occurs 12 times in the data base with non-future time-reference. $R \bar{a} h \underline{h}$ and its equivalent $h a-$ as well as rāyih thus basically appear when the time-reference is future. Hence, these particles can, with a rather high degree of certainty, be considered markers of future tense. The particle ha- was mainly noted in the speech of one young mother from Abu Dhabi. Reportedly, the particle ha- is used in some villages around Nizwa. ${ }^{46}$ Răh occurs in the speech of several informants from Oman and a number of young Kuwaiti informants as well as one Bahraini informant together with eight instances from Fujairah and one from Abu Dhabi in the UAE. Hence, the database so far indicates that $r \bar{a} h$ is more common in the Omani cultural and geographical sphere and possibly also in Kuwait than in other areas of the Gulf. Though I have no statistics for this yet, my impression is that these particles are used mainly by younger, educated speakers. ${ }^{47}$

46 Hamad Al Bu Sa'id, personal communication.

${ }^{47}$ Comments heard in Nizwa that it is 'Muscat dialect' leads one to think that the use of $r \bar{a} h$ is marked by prestige and/or fashion. We must not forget, though, that $h a$ - is not a recent future marker in the Omani dialect. Cf. Reinhardt 1894, 149f, 287-290. It may be assumed that the use of $r \bar{a} h / h a$ - has been reinforced by the fact that virtually all schoolteachers in Oman from the 1970s until recently have been of either Levantine or Egyptian origin. As for Kuwait, where labour force immigration started at a considerably earlier stage, we find that 
I will return to the use of $b$ - in conditional clauses and main clauses with some proposals to an explanation shortly. Let us, however, first consider the suggested modal values of this prefix.

The use of $\mathrm{b}$ - and rāh as modal markers

The $b$-prefix is mentioned in the literature both as a temporal and as a modal marker or a combination of both. As a modal marker it is said to imply intent or volition. Most references suggest that the Gulf Arabic $b$ stems from the verb(s) baga (p-stem: yabgi) and yabi meaning 'to want'. ${ }^{48}$ The verb(s) baga/yabi in their full forms are used sparingly in the present database. Only 26 instances are found in the corpus and they are all expressions of volition. ${ }^{49}$

A grammaticalization process, by which a word originally meaning wish/want/intend develops into a future tense marker, is not at all

already Johnstone 1967, xxviii reports a strong Egyptian and Levantine influence on the local dialect. Borrowing may thus be a factor to consider when analysing the use of $r \bar{a} h$ in Kuwaiti and other Gulf Littoral dialects.

48 Brocket 1985, 21; Cohen, M 1924, 63ff; Holes 2004, 247, n.29; Al-Tajir 1982, 80. Ingham 1994, 94, 120 (in accordance with Nöldeke 1904, 67) considers $y a b a$ to be a reduced form of yabgi. Such a common origin can explain that 'both' verbs are mentioned as the source of the $b$-prefix.

${ }^{49}$ Examples are such as:

kānat tabi tilabbis-na ahdat šē.

be3sg.f.s-stem want3sg.f.p-stem dress3sg.f.p-stem-us more.modern thing

She wanted/used to want to dress us in the latest thing (middle-aged female, Manama, Bahrain).

Sometimes they seem to be used more as a particle than as a full verb, i.e. to be on their way to be grammaticalized as a modal marker. Cf. Ingham 1994, 120. Thus, in the following example from Kuwait where the verb yaba is not conjugated for number,

halas! yirūḥūn hadāāyiq u yirūhūn yil abūn mallū! yiba yrūḥūn li-l-barr.

Enough! go3pl.m.p-stem parks and go3pl.m.p-stem play3pl.m.p-stem, get.bored3pl.m.s-stem! want3sg.m.p-stem go3pl.m.p-stem to-the-desert

Enough! They go to parks and they go and play. They're bored. They want to go to the desert!

(Young mother, Kuwait)

Tim Peverill (personal communication) reports the use of baga in the form of the active participle in Nizwa. As in the p-stem variety yaba the $/ \dot{\mathrm{g}} /$ is lost in the feminine AP giving the forms bāyig/bāyeh, 'wanting,' for masculine/feminine respectively. It is easy to see how these forms could be further diminished into a $b(a)$-prefix. Curiously enough, however, my data from Nizwa contains only limited instances of the $b$-prefix; the particle $r a \bar{h}$ being much more frequent. 
uncommon in the languages of the world. ${ }^{50}$ English is an obvious example of this and an example from Arabic dialects is provided by Maltese in the form of the future particle se. ${ }^{51}$ Future markers across languages are in general more or less optional; that is to say, most languages have a variety of ways in which they express the future. Moreover, future is seldom if ever a truly temporal category. More often than not, markers of future tense come with various modal meanings. ${ }^{52}$ Sometimes the converse is also true and it is important here to note that intention often comes with a tint of futurity. Bybee, Perkins and Pagliuca go as far as to assume that all futures go through a stage of functioning to express intention. ${ }^{53}$ They propose that:

intention is the crucial bridge to prediction and that the change from intention to prediction occurs via the inferences that hearers make on the basis of the speaker's utterance. The more common sources for futures are those that yield the intention inference most easily - desire, strong obligation, and movement toward a goal. ${ }^{54}$

Hence, if the Gulf Arabic $b$-prefix is both a future marker and a marker of intentive mood, and especially if it has developed from a verb meaning to wish/want/intend, it could be assumed that the function as a marker of future tense is a secondary function to the modal one. I have therefore surveyed the various modal contexts in which the $b$-prefix occurs in search for predicates and contexts expressing an intention to act. Intention was given a broad definition so that I would not exclude anything that could be analysed as intentive. I found 213 predicates situated in a context that expressed some kind of conscious intention to act. As may be expected, almost all express intention towards a future action, but a handful (20), mainly conditional clauses, express intention that is not directed to any particular time:

5. Al-ḥēne yōm $b$-aḥuṭt šāy hina dāḩil $b$-abannid al-bāb

50 Bybee et al. 1994, 254; Heine and Kuteva. 2005, 104. See also Bybee et al. 1994, 279f and Palmer 2001, 105.

51 Ebert 2000, 763.

52 Cf.. Fleischman 1982, 24 who concludes that 'The future tense of all languages $[\ldots]$ is always partly temporal and partly modal. In many languages reference to future world-states is in fact grammaticized in the category of mood rather than tense'.

53 Bybee et al. 1994, 254.

54 Ibid., 279f. 
the-time when $b$-place1sg.p-stem thing here inside $b$-close1sg.p-stem the-door

Now if/when I place something here inside, I close the door. ${ }^{55}$

121 of the clauses expressing conscious intention are introduced by the $b$-prefix. 26 of the predicates were futures introduced by $r a \bar{h} h$, one by $h a$ and one was preceded by rayih. Four are examples of the use of the verbs $b a \dot{g} a / y a b i$ to express volition or intention:

6. Lo wāhid hindi hināk $b$-isawwi ${ }^{c}$ alēna yikūn kalb yabi yiḍbaḥna ma na ${ }^{c}$ rif huwe šu yiqūl

If one Indian there $b$-do3sg.m.p-stem on.us be3sg.m.p-stem dog want3sg.m.p-stem sacrifice3sg.m.p-stem us not know1pl.p-stem he what say3sg.m.p-stem

If an Indian out there would do something against us, if he'd be a bastard, want to cheat us, we wouldn't know what he's saying. ${ }^{56}$

In addition to these, I count 64 instances of future conscious intention that is unmarked. All this goes to say is that $b$ - at least is not a necessary marker of intention, just as it is not a necessary marker of future; neither of which should surprise us - indeed only the opposite-viz. a necessary marker for either of these would be surprising. ${ }^{57}$ However, more significant in this respect is the observation that $b$ - is also used together with verbs with non-personal subjects, as well as with verbs expressing state, ability and so on, i.e. where intention can not be at hand: ${ }^{58}$

7. Al-insān lo ma yiba yimūt $b i$-ymūt gūwa heeh $b i$-ymūt gūwa the-man if not want3sg.m.p-stem die3sg.m.p-stem $b$-die3sg.m.p-stem force aye $b$-die3sg.m.p-stem force

If man doesn't want to die he'll die against his will, aye he'll die against his will. 59

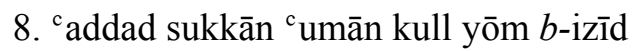

number inhabitants Oman every day $b$-increase3sg.m.p-stem

55 Elderly male, Fujairah, UAE.

${ }^{56}$ Elderly male, Fujairah, UAE.

57 Cf. Cohen, D. 1984, 281, Fleischman 1982, 2.

58 According to Brustad 2000, 243, the Kuwaiti b-prefix can function as a marker of intention also outside the scope of the human will. However, neither the context of the example she provides for this nor her translation suggests an intentive rather than a future reading.

59 Elderly female, Fujairha, UAE. Note the use of the verb baga/yabi for volition here. 
The number of inhabitants in Oman will increase/increases every day. 60

9. fi-l-mustaqbal al-ihwān ma $b$-ya ${ }^{c}$ rifu ba ${ }^{c} d$ in the-future the-brothers not $b$-know3pl.m.p-stem each other In the future brothers won't know each other. ${ }^{61}$

It therefore seems as if the context is more decisive than the presence or absence of $b$ - to signal intention. At least, if $b$ - has an intentive meaning, this connotation is not strong enough to bar the particle from use in contexts where intension is excluded. This leads to the question what previous scholars might have had in mind when they described $b$ - as being intentive. We could be watching a diachronic development, my data being considerably more recent than most of the other studies made on these dialects. I find it likewise possible, though, that older works that state that $b$ - signals 'future with a hint of intention' and similar reports have overlooked the fact that future in itself often comes with 'a hint of intention' and therefore ascribed this modality to the $b$-prefix. It is interesting to remember in this context that Holes, whose observations are more recent, also ascribe intentionality to the $b$-prefix:

In $[\ldots]$ Gulf littoral dialects generally $[\ldots]$ there is a contrast between baru: $h$ 'I'm going to go' (intention) and ?abbi aru:h 'I'd like to go. ${ }^{62}$

The distinction Holes draws is one between intention and volition, not between future and intention. Furthermore, the example he gives for intention (baru:h 'I'm going to go') suggests that he does not, in this context, make a distinction between conscious intent, on one hand, and the general sense of intent often connected with future, on the other.

Contrary to what is often assumed, the $b$-prefix in the surveyed data does thus not seem to be used as a marker of the intentive mood. This observation is pertinent since the connection between this marker and the intentive mood has been so strongly asserted for these and related dialects.

Instead, we have here a prefix which may and may not be used in contexts with future reference, which may and may not be used in contexts expressing intent, and which may and may not be used in conditional clauses. In addition, it is used in a number of ordinary main

\footnotetext{
${ }^{60}$ Middle-aged, male teacher, Nizwa, Oman.

61 Young, educated female, Buraimi, Oman.

62 Holes 2004, 247 n.29.
} 
clauses that fall outside these criteria. ${ }^{63}$ I will return to these shortly. We will, however, first revisit the most dominant use of the $b$-prefix outside of the future context, viz. the result clauses of conditions where $r \bar{a} h$ is also used to a notable extent.

The use of b- in main clauses and its relation to the use of b- in future and conditional contexts. Suggestions for a unified interpretation

Verbs used to express the future tense are used also for the conditional in other languages in the world, though the verb form used in each context is often not the same. Thus we can, for example, talk about the conditional mood in English. Past forms of future markers are common in languages. ${ }^{64}$ Hence, the appearance of future markers in this context is not surprising. Strange as it may seem at first sight, we can also accommodate the use of $r \bar{a} h$ and the $b$-prefix in conditionals within a theory that interprets them as future markers, viz., if we look at the clauses from the speaker's perspective. The speaker may, when asked about how life would have been if he/she had lived a long time ago, make a temporal journey in his/her mind perhaps along the lines of: 'if we imagine how it would have been had I lived thirty years ago, what will we then find? In such an imaginary world into which I am now going to put myself, I will be living in a tent and I will marry at young age....' In other words, the speaker may think of creating an imaginary world and then consider what will be the consequences as he builds up the scenery. In such a context the use of future is logical. This is similar to that which Tedeschi suggests when expanding on his theory of branching futures. 'Our intuitions about the analysis of counterfactual sentences', he says, 'indicate that we are considering truth relations with respect to a possible, albeit unrealized, future of a past time'. ${ }^{65}$ Furthermore, 'we evaluate counterfactual conditional sentences as if we returned to the past and looked at possible futures with respect to that past' ${ }^{66}$ This kind of reasoning works for both protases and apodoses:

63 It may be noted in this context that a selection of the database was also tested for the collocation of $r \bar{a} h$ and $b$ - with stative vs. dynamic and telic vs. atelic verbs. No correspondence between these factors and the use of the markers were found. Cf. Persson 2006.

64 Bybee 1985, 194f. Cf. English would (past form of will) and should (past form of shall) as well as Swedish skulle (past form of skall).

65 Tedeschi 1981, 255f.

66 Ibid. Brustad 2000, 202 makes a similar statement about the role of the speaker's perspective, not about time-reference or tense but about aspects, 'As a means of representation, aspect is controlled by the speaker, who chooses 


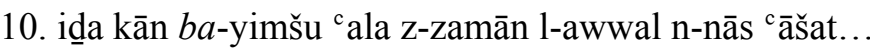

if be3sg.m.s-stem $b$-walk3pl.m.p-stem prep the-time the-first thepeople live3sg.f

If they were to do as in old times, then people lived...67

11. al-yōm $b a$-yitnāza ${ }^{c} u$ bākir $b a$-yiriddu yisōlifu $\mathrm{ma}^{\mathrm{c}} \mathrm{ba}^{\mathrm{c}} \mathrm{d}$

the-day $\quad b$-argue3pl.m.p-stem tomorrow $\quad b$-return3pl.m.s-stem

chat3pl.m.s-stem with one.another

If they fight today, they'll chat with each other again tomorrow. 68

Following the theory of branching futures, the use of $b$ - in 10 would come out of an (unconscious) 'reasoning' on the lines of 'lets go to a time where it is true that 'they are going to walk according to old times', then the conclusion is...'. Similarly, the use of $b$ - in both protasis and apodosis of 11 can be explained by an imagined reasoning saying 'let's go to a point today where it is true that 'they will fight', then it is also true that "tomorrow they will chat again". ${ }^{69}$

To these explanations regarding the use of future in conditionals, we may add that futures also often have a conditional trait in the sense that their fulfilment often depends on certain conditions. ${ }^{70}$ Ingham even states that, 'In the Arabic system it seems that all future events, being uncertain, are treated as conditionals' ${ }^{71}$ Thus, it is not only the case that there may be good reasons for the use of future tense in (non-future) conditionals, but it is also the case that futures share traits with conditionals. This leads us to a consideration of the modal aspects of futures and conditionals. The above discussion about time-reference and time perspective in conditional clauses may be helpful towards explaining the use of the $b$-prefix in conditional clauses. Another feature in the data remains, however, unexplained viz. the use of $b$ - in ordinary main clauses. Of the 126 collected instances of $b$-prefix in non-future

aspectual representation according to his or her perspective of an action or event'. Fleischman 1982, 20f comments on the role of the speaker's perspective saying that '....all too often in attempts to reconcile time and tense the focus is exclusively on sequence of events in real time, while the crucial role of speaker's perspective is neglected'.

${ }^{67}$ Elderly saleswoman, Sur, Oman.

68 Young, educated female, Buraimi, Oman.

${ }^{69}$ For a discussion on Tedeschi's theory with applications, see also Dahl 1997, 101-107.

70 Fleischman 1982, 20.

${ }^{71}$ Ingham 1994, 133. 
contexts, 43 or about one third are found in ordinary main clauses. A study of these in search for common traits reveals that half of them (22) are expressions of habitual actions in the past. ${ }^{72}$ Palmer discusses how habitual past in some languages is treated as irrealis in spite of the observation that past time-reference usually receives realis marking. He points out that habitual past is about a tendency to act rather than about specific actions that took place in the past. Palmer also refers to Givón's comment that the habitual, while sharing with the realis in denoting a 'higher assertive certainty', also has irrealis features such as 'lack of specific temporal reference' and 'lack of specific evidence'. ${ }^{73}$ Palmer goes on to relate Chung and Timberlake's observation that English uses a modal verb to express habitual action: 'We would go for a walk most weekends'. ${ }^{74}$ Even more interesting for us is Palmer's remark that the uses of WILL in English share the potentially irrealis meaning of tending to act, and that this may easily be interpreted as either conditional future (i.e. conditional upon other events) or as habitual. Furthermore, it appears that the 'future tense' in Dyirbal is used for habitual actions too and might thus be considered to be a mood rather than a tense. ${ }^{75}$

Habituality is an aspectual trait; it has to do with the internal temporal structure of the event. Conditionality is modal in the sense that it describes the actuality of the event in terms of what could possibly be/have been. Future, as dealt with here, is a tense, i.e. it locates the event in a time frame. Neither aspect nor tense is shared between the instances of $b$ - found in the database. Could then the reason for this shared feature of a number of future, conditional and habitual sentences be something that has more to do with the way in which these statements are viewed by the speaker than with their temporal location or structure? Perhaps Givón's comment above can lead us to a possible solution. Habituals share with conditionals in lacking both 'a specific temporal reference' and 'specific evidence'. Futures, likewise, lack 'evidence' since they have not happened and that makes even their time-reference more unclear; what has not yet happened cannot be decisively fixed on the time line since it may still not happen. What we have here in all three

\footnotetext{
72 A cross-check in the total database shows 92 instances of habitual past that are not marked by the $b$-prefix. In 67 of these, the auxiliary verb $k \bar{a} n$ 'to be' is used to signal habitual actions in the past.

73 Givón 1994, 323 quoted in Palmer 2001, 179, 191.

74 Palmer 2001, 179 referring to Chung and Timberlake 1985, 221.

75 Palmer 2001, 191 referring to Roberts 1994, 23 who based his statement on data from Dixon 1972, 55.
} 
cases are statements about something that cannot be proved. The $b$-prefix is used for assumptions about a world that has not been experienced (futures, conditionals) or generalisations about past tendencies (habitual pasts). It is worth noting that in most of the habitual pasts where the $b$ - is used the speaker has not himself experienced the past he is relating. He is relating what his parents' generation has told him. The $b$ - is thus used for the unlived, the non-evidential. Mithun's definition of the realis/irrealis distinction may be helpful here:

The realis portrays situations as actualized, as having occurred or actually occurring, knowable through direct perception. The irrealis portrays situations as purely within the realm of thought, knowable only through imagination. ${ }^{76}$

The $b$-prefix in my data fits well into this definition. That a language has a marker for irrealis modality does not simply imply that everything that is not marked as irrealis is by definition realis, i.e. that all unmarked forms are notionally realis. Rather, languages that make a realis/irrealis distinction vary in the scope of these two categories. ${ }^{77}$ Reportedly, in some Papauan languages future is the only category marked as irrealis; ${ }^{78}$ in others irrealis marking covers the imperative as well; in others still counterfactual is included and then there is one example where future, imperative, counterfactual and habitual past are all marked as irrealis. ${ }^{79}$ Palmer describes a marker in the Native American language Kiowa that has been said to denote future, and that definitely seems to indicate future, but that is also used in many contexts that may be described as irrealis such as stating a future that did not occur, the conditional or an obligation. Kiowa has, however, other markers for the imperative and the negative imperative as well as for 'hearsay'. The future-cum-irrealis marker in Kiowa does thus not belong to an organized system of realis/irrealis or even realis/irrealis/unmarked ${ }^{80}$ On a hierarchy ranging from the most prototypical realis to the most prototypical irrealis, future seems to hit the end on the irrealis side in most languages. This does not mean, though, that a language that has irrealis marking for the future

\footnotetext{
76 Mithun 1999, 173 quoted in Palmer 2001, 1, See also Mithun 1995, 368.

77 See Palmer 2001 for an extensive discussion. Cf. also Mithun 1995, 386.

${ }^{78}$ In which case the marking could be one of tense just as well as one of mood.

79 Palmer 2001, 159 referring to a table in Roberts 1994, 31.

80 Palmer 2001, 163f. Palmer refers to Watkins 1984, 170-2 where the marker is glossed as a future marker, and Mithun 1999, 173 who treats the same marker as irrealis.
} 
cannot leave futures unmarked or even mark future tenses as realis. ${ }^{81} \mathrm{I}$ mentioned above that counterfactuals can be marked as irrealis. Palmer also reports several languages in which conditionals are marked as irrealis. ${ }^{82}$

The corollory of the above suggests that Gulf Arabic $b$-prefix, which is used to quite some extent for futures, conditionals and habitual past, has much in common with markers of irrealis in some other languages. That not all categories which are notionally irrealis receive this marking is not relevant since languages differ in what can receive irrealis marking. Also, irrealis being a modal distinction, the speaker may choose to mark this or not according to pragmatic and other speechsituation oriented choices.

This conclusion about the irrealis character of the $b$-prefix does not disqualify the traits shared between future and conditionals as discussed above. The reasons for using $b$ - in conditionals may very well be a combination of its character as an irrealis marker as suggested here and of a speaker-oriented perspective frame putting the past conditional event in a future time frame. The one can have developed out of the other. ${ }^{83}$ If the $b$ - has developed from the verb(s) bagalyabi, 'to want', then the overall meaning of irrealis may be the one that has remained and made the particle suitable for all three contexts. However, the association of this particle with the future seems to have been and still be strong and this may have led to its use in conditionals as described above, with the irrealis connotation reinforcing its suitability for use in this context. We may recall Tedeshi's words that: 'we are considering truth relations with respect to a possible, albeit unrealized, future of a past time. ${ }^{84}$

The remaining twenty, non-future main clauses with $b$-prefix that have so far been recorded do not display any obvious shared traits. It may be noted, however, that seven of the predicates encode a mild form of obligation corresponding to English should. This also falls within the realm of irrealis. A larger sample and further study on how this kind of obligations are generally encoded in Gulf Arabic is needed before conclusions on the use of the $b$-prefix in these few remaining cases can be drawn.

\footnotetext{
81 Mithun 1995, 378, Palmer 2001, 168f.

82 Palmer 2001, $177 \mathrm{f}$.

83 Fleischman 1982, 23f notes the bi-directionality in the development of modals from futures and vice-versa.

84 Tedeschi 1981, 255f, my emphasis.
} 


\section{Summary and concluding comments}

This study was undertaken to examine the use of the $b$-prefix in order to establish whether or not this is a tense- and/or a marker of the intentive mood as has been assumed. Other possible uses of the $b$-prefix were explored in order to find out what this prefix is used for if it is not a marker of future tense or intentive mood. Finally, I looked for other possible future markers than the $b$-prefix.

The research survey established the use of one rather obvious future marker, the particle $r \bar{a} h$, at least in some parts of the dialectal area. This particle has received little attention in the literature on the Gulf Arabic dialects following Johnston's descriptions from 1967. On the other hand, the verb(s) baga/yabi, that have been mentioned as indicators of future time in the nearby Najdi dialect, turned in the present database out to be used only for the volitive, viz. to express a wish and not to signal future time-reference.

However, the most important result of the study is that the $b$-prefix cannot be said to be a pure marker of future tense. Similar to so-called future markers in many other languages futurity is one - but not the only or necessarily the most important one - of its connotations. Although the $b$-prefix does co-occur with the future, it is much more consistently used in conditional clauses. Furthermore, it has a significant use in main clauses expressing the habitual past. The $b$-prefix does also not seem in any way to be an obvious marker of the intentive mood. The most important argument here is that it can occur in contexts where intention is impossible.

Instead, the main characteristic of the $b$-prefix is here suggested to be as a marker of irrealis/a marker of some notionally irrealis categories. This does not imply that Gulf Arabic has a binary system for marking the realis/irrealis distinction, only that it has a marker that can be used to mark some events as 'purely within the realm of thought, knowable only through imagination.' All three areas of language where the $b$-prefix is more or less systematically used - future time-reference, conditionals and past habituals - can be characterised as notionally irrealis. Thus, where the labels 'future' and 'intentive' fail, the notion of irrealis seems to account well for all the uses of $b$ - as recorded in the rather large database that has been surveyed for this study. Continued work on tense, aspect and mood in Gulf Arabic, viz. the kind of research carried out within the larger project of which this treatise is a part, will hopefully throw more light on this and related questions such as the use of the $b$ prefix in main clauses that do not express the habitual past. The data suggests that a broader study of how other notionally irrealis categories 
are encoded in Gulf Arabic may be fruitful. Further research is also needed on other types of texts as well as on a broader range of speakers in terms of age and social environment to see if the use of $b$ - as described here is language general or limited to certain types of discourse and/or classes of speakers.

\section{REFERENCES}

Abboud, Peter Fouad. 1964. The Syntax of Najdi Arabic. Ann Arbor: University Microfilms International.

Badawi, Elsaid, Carter, Michael G. and Gully, Adrian. 2004. Modern Written Arabic. A Comprehensive Grammar. London and New York: Routledge.

Brockett, A. A. 1985. The Spoken Arabic of Khābūra on the Bātina of Oman. Journal of Semitic Studies, Monograph No. 7. Manchester: University of Manchester.

Brustad, Kristen E. 2000. The Syntax of Spoken Arabic. A Comparative Study of Moroccan, Egyptian, Syrian and Kuwaiti Dialects. Washington: Georgetown University Press.

Bybee, Joan L. 1985. Morphology. A Study of the Relation between Meaning and Form. Amsterdam and Philadelphia: John Benjamins.

Bybee, Joan L., Perkins, Revere D. and Pagliuca, William. 1994. The Evolution of Grammar: Tense, Aspect and Modality in the Languages of the World. Chicago: University of Chicago Press.

Chung, Sandra and Timberlake, Alan. 1985. 'Tense, Aspect and Mood' in Shopen, T. (ed.). Langauge Typology and Syntactic Description. Cambridge: Cambridge University Press, vol. 3, 202-58.

Cohen, David. 1984. La Phrase nominale et l'évolution du système verbal en sémitique. Études de syntaxe historique. Leuven and Paris: Peeters.

Cohen, Marcel. 1924. Le Système verbal sémitique et l'expression du temps. Paris: Éd. Ernest Leroux.

Comrie, Bernard. 1976. Aspect. Cambridge: Cambridge University Press

—. 1985. Tense. Cambridge: Cambridge University Press.

Cowan, William. 1966. 'Two Notes on Arabic Dialectology' in Journal of the American Oriental Society 86/4: 416-418.

Cuvalay, Martine. 1994. 'On the Role of 'Tense' in Conditional Sentences' in Caubet, Dominique and Vanhove, Martine (eds.) Actes des premières journées internationales de dialectologie arabe de Paris: Colloque international tenu à Paris du 27 au 30 janvier 1993. Paris: Inalco, 235-249 
Dahl, Östen. 1997. 'The Relation between Past Time Reference and Counterfactuality' in Athanasiadou, Angeliki and Dirven, René (eds.) On Conditionals Again. Amsterdam and Philadelphia: John Benjamins, 97-114.

Dixon, R. M. W. 1972. The Dyirbal Language of North Queensland. Cambridge: Cambridge University Press.

Ebert, Karen H. 2000. 'Aspect in Maltese' in Dahl, Östen (ed.) Tense and Aspect in the Languages of Europe. Berlin and New York: Mouton de Gruyter, 753-785.

Eisele, John. C. 1990. 'Time Reference, Tense, and Formal Aspect in Cairene Arabic' in Eid, Mushira (ed.) Perspectives on Arabic Linguistics I. Amsterdam: Benjamins, 173-233.

Eksell, Kerstin. 2006. 'The Origin and Development of the Cursive $b$ Imperfect in Syrian Arabic' in Eksell, Kerstin and Vinther, Thora (eds.) Change in Verbal Systems. Issues on Explanation. Frankfurt am Main and New York: Peter Lang, 73-98.

Feghali, Habaka J. 2004. Gulf Arabic. The Dialects of Riyadh and Eastern Saudi Arabia. Grammar, Dialogues and Lexicon. Springfield: Dunwoody Press.

Fischer, Wolfdietrich and Jastrow, Otto. 1980. Handbuch der arabischen Dialekte. Wiesbaden: Harrassowitz.

Fleischman, Suzanne. 1982. The Future in Thought and Language. Diachronic Evidence from Romance. Cambridge: Cambridge University Press.

Givón, Talmy. 1994. 'Irrealis and the Subjunctive' in Studies in Language, 18: 265-337.

- 1995. Functionalism and Grammar. Amsterdam: Benjamin.

Holes, Clive. 2000. Dialect, Culture and Society in Eastern Arabia, Volume 1: Glossary (Handbuch der Orientalistik). Leiden and Boston: Brill.

- 2004. Modern Arabic: Structures, Functions, and Varieties, (revised edition). Washington: Georgetown University Press.

Heine, Bernd and Kuteva, Tania. 2005. Language Contact and Grammatical Change. New York and Cambridge: Cambridge University Press.

Ingham, Bruce. 1994. Najdi Arabic: Central Arabian. Amsterdam and Philadelphia: John Benjamins.

Johnstone, T. M., 1967. Eastern Arabian Dialect Studies. London: Oxford University Press.

Jong, Rudolf de. 2000. A Grammar of the Bedouin Dialects of the Northern Sinai Littoral. Bridging the Linguistic Gap between the 
Eastern and Western Arab World. (Handbuch der Orientalistik). Leiden: Brill.

Kaye, Alan S. 1976. Chadian and Sudanese Arabic in the Light of Comparative Arabic Dialectology. The Hague: Mouton.

Kaye, Alan S. and Rosenhouse, Judith. 1997. 'Arabic Dialects and Maltese', in Hetzron, Robert (ed.) The Semitic Languages. London: Routledge.

Khan, Geoffrey. 1988. Studies in Semitic Syntax. Oxford: Oxford University Press.

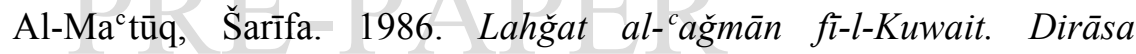
lugiawiyya. Doha: Markaz at-turāt aš-ša ${ }^{c}$ bi li-duwal al-halīğ alcarabiyya.

Mitchell, T.F. and El-Hassan, S. A. 1994. Modality, Mood and Aspect in Spoken Arabic, with Special Reference to Egypt and the Levant. London and New York: Kegan Paul International.

Mithun, Marianne. 1995. 'On the Relativity of Irreality'. In Bybee and Fleischman (eds) Modality in Grammar and Discourse. Amsterdam and Philadelphia: John Benjamins, 367-388.

- 1999. The Languages of Native North America. Cambridge: Cambridge University Press.

Noonan, Michael. 1985. 'Complementation' in Shopen, Timothy (ed.) Language Typology and Syntactic Description, 3 vols, Cambridge: Cambridge University Press, vol. 2, 42-140.

Nöldeke, Theodor. 1904. Beiträge zur semitischen Sprachwissenschaft. Strassburg: Trübner.

Owens, Jonathan. 1993. A Grammar of Nigerian Arabic. Wiesbaden: Harrassowitz.

Palmer, F. R. 2001. Mood and Modality. (2nd ed.) Cambridge: Cambridge University Press.

Persson, Maria. 1999. 'Semantic Considerations in the Syntactic Structures of Complement Clauses in Modern Literary Arabic' in Yasir Suleiman (ed.) Arabic Grammar and Linguistics. London: Curzon, 182-202.

- 2002. Sentential Object Complements in Modern Standard Arabic. Studia Orientalia Lundensia. Nova Series. vol. 2, Stockholm: Almqvist and Wiksell.

- 2006a. The Use of the Active Participle in Gulf Arabic, Paper presented at The Divisions of Culture and Heritage and of Language and Communication, United Arab Emirates University, 18 February 2006. 
—. 2006b. 'Jag ville jag vore' $i$ Arabia land ('I wish I were' in Arabia). Paper presented at Nordiska semitistsymposiet, Kivik, Sweden, 2-4 August 2006.

—. 2008a. Det gulfarabiska b-prefixet - en irrealismarkör snarare än markör för futurum/intention. (The Gulf Arabic b-prefix - a marker of irrealis rather than future/intention). Paper presented at Grammatik $\mathrm{i}$ Fokus, Lund University, Sweden, 7-8 February 2008.

- 2008b. Progressiv och habituell aspekt i gulfarabiska (Progressive and habitual aspect in Gulf Arabic) Paper presented at Nordiska semitistsymposiet, Kivik, Sweden 13-16 August 2008.

—. 2008c. An Interesting Typological Compromise. Report from a Corpus Based Study of Modal and Aspectual Markers in Gulf Arabic Dialects. Paper presented at AIDA 8, Essex University, Colchester 28-31 August 2008.

Qafisheh, Hamdi A. 1977. A Short Reference Grammar of Gulf Arabic. Tucson, Arizona: University of Arizona Press.

Reichmuth, Stefan. 1983. Der arabische Dialekt der Sukriyya im Ostsudan. Hildesheim: Olms.

Reinhardt, Carl. 1894. Ein arabischer Dialekt gesprochen in ${ }^{\circ}$ Omān und Zanzibar. Stuttgart and Berlin: W. Spemann.

Roberts, John R. 1994. 'The Category 'Irrealis' in Papuan Medial Verbs' in Notes on Linguistics 67: 5-41.

Al-Tajir, M.A. 1982. Language and Linguistic Origins in Bahrain. The Baharnah Dialect of Arabic. London: Kegan Paul International.

Tedeschi, Philip. 1981. 'Some Evidence for a Branching-Futures Semantic Model' in Tedeschi, Philip and Zaenen, Annie (eds.), Syntax and Semantics 14: Tense and Aspect. New York: Academic Press, 239-270.

Trask, Robert L. 1993. A Dictionary of Grammatical Terms in Linguistics. London and New York: Routledge.

Van Valin, Robert D. Jr. and LaPolla, Randy J. 1997. Syntax: Structure, Meaning and Function. Cambridge: Cambridge University Press.

Watkins, Laurel J. 1984. A Grammar of Kiowa. (Studies in the Anthropology of North American Indians). Lincoln: University of Nebraska Press. 